Cite this: Chem. Commun., 2014, 50,2431

Received 10th December 2013, Accepted 15th January 2014

DOI: $10.1039 / c 3 c c 49385 g$

www.rsc.org/chemcomm

\section{Isolation of a potassium bis(1,2,3-triazol-5- ylidene)carbazolide: a stabilizing pincer ligand for reactive late transition metal complexes $\dagger$}

\author{
Daniela I. Bezuidenhout, ${ }^{\mathrm{ab}}$ George Kleinhans, ${ }^{\mathrm{a}}$ Gregorio Guisado-Barrios, ${ }^{\text {bc }}$ \\ David C. Liles, ${ }^{a}$ Gaël Ung ${ }^{b}$ and Guy Bertrand*b
}

The synthesis and X-ray crystal structure of a potassium adduct of a monoanionic CNC-pincer ligand featuring two mesoionic carbenes is reported. Owing to the peculiar electronic and steric properties of this ligand, the first neutral stable $\mathrm{Ni}(\mathrm{II})$-hydride, and an unusual $\mathrm{Cu}($ II) complex displaying a seesaw geometry, have been isolated.

It is well known that tridentate pincer ligands not only give rise to robust catalysts, but also allow for isolating extremely reactive metal centers. ${ }^{1}$ A large number of both neutral and monoanionic pincer ligands featuring $\mathrm{N}$-heterocyclic carbenes (NHCs) have been prepared, and the corresponding complexes used as catalysts for various chemical transformations. ${ }^{2}$ However, only four complexes, featuring a strongly donating amido-moiety as the central coordinating atom, flanked by two NHC wing-tip groups in a CNC-fashion, have been reported (A-C) (Chart 1). ${ }^{3}$ Moreover, pincer ligands based on the novel generation of carbenes, namely mesoionic carbenes (MICs), ${ }^{4}$ which are even stronger donors than NHCs, have been even less explored. For the CCC-tridentate binding mode, a handful of examples are known with imidazol-4-ylidenes, ${ }^{4,5}$ whereas with 1,2,3-triazol-5-ylidenes, ${ }^{6}$ binuclear bridged complexes ${ }^{7}$ or mononuclear complexes with bidentate ligands where the central C-atom does not ligate, ${ }^{8}$ are exclusively found. A neutral CNC-analogue of tridentate terpyridine, [2,6-bis(1,2,3-triazol-5-ylidene)-pyridine], is the only example of a bisMIC pincer acting as a tridentate ligand. ${ }^{9}$ Here we report the synthesis of the first stable anionic CNC-tridentate ligand featuring terminal 1,2,3-triazol-5-ylidenes and a central

\footnotetext{
${ }^{a}$ Chemistry Department, University of Pretoria, Private Bag X20, Hatfield 0028, Pretoria, South Africa. E-mail: daniela.bezuidenhout@up.ac.za; Tel: +27 4202626 ${ }^{b}$ UCSD-CNRS Joint Research Laboratory (UMI 3555), Department of Chemistry and Biochemistry, University of California, San Diego, La Jolla, CA 92093-0343, USA. E-mail: guybertrand@ucsd.edu; Tel: +1 8585345412

${ }^{c}$ Departamento de Quimica Inorganica y Organica, Universitat Jaume I,

Avenida Vicente Sos Baynat s/n, 12071 Castellon, Spain

$\dagger$ Electronic supplementary information (ESI) available: Synthetic procedures and analytical data; CIF files for single crystal X-ray structural analysis. CCDC 956921956923, 957055 and 972504. For ESI and crystallographic data in CIF or other electronic format see DOI: 10.1039/c3cc49385g
}

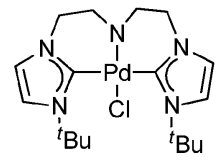

$A^{3 a}$

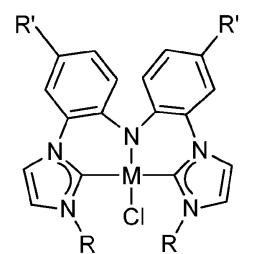

$B$

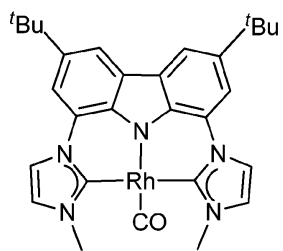

$c^{3 d}$
$\mathrm{M}=\mathrm{Pd}, \mathrm{R}={ }^{i} \mathrm{Pr}$ or ${ }^{n} \mathrm{Bu}, \mathrm{R}^{\prime}=\mathrm{Me}^{3 \mathrm{~b}}$

$\mathrm{M}=\mathrm{Pt}, \mathrm{R}={ }^{i} \mathrm{Pr}$ or ${ }^{n} \mathrm{Bu}, \mathrm{R}^{\prime}=\mathrm{H}^{3 \mathrm{C}}$

Chart 1

amido functionality, its mononuclear tridentate $\mathrm{Ni}$ (II)-hydride and $\mathrm{Cu}$ (II) complexes.

The planar carbazole backbone with its rigid geometry seemed an attractive choice for the design of a bis(mesoionic carbene)amido pincer-type ligand. The synthesis of the dicationic salt precursor, namely the bis(1,2,3-triazolium)carbazole 1, was achieved in $43 \%$ yield by an adapted version of the formal 1,3-dipolar cycloaddition between a 1,3-diaza-2-azoniaallene salt and a 1,8-diethynylcarbazole (Scheme 1). ${ }^{6 a}$ Addition of 3 equivalents of potassium hexamethyldisilazide (KHMDS) to a THF solution of $\mathbf{1}$ at $-78{ }^{\circ} \mathrm{C}$ resulted only in the deprotonation of the carbazole, keeping unchanged the two pendant 1,2,3-triazolium moieties. The cationic salt 2 was isolated in 93\% yield as an air- and moisture-stable red solid. The monodeprotonation of $\mathbf{1}$ is indicated by the absence of the $\mathrm{N}-\mathrm{H}$ resonance in the ${ }^{1} \mathrm{H}$ NMR spectrum, and by the presence of a triazolium $\mathrm{C}-\mathrm{H}$ signal $(2 \mathrm{H})$ at $10.03 \mathrm{ppm}$ (see ESI $\dagger$ ). The structure of 1 was confirmed by an X-ray diffraction study (Fig. 1). When a large excess of KHMDS ( 5 equivalents) was added to a diethylether suspension of $\mathbf{1}$ at $-78{ }^{\circ} \mathrm{C}$, the potassium salt $\mathbf{3}$ could be isolated in good yield (72\%) after extraction with hexanes. In the ${ }^{1} \mathrm{H}$ NMR spectrum, the disappearance of the acidic $\mathrm{N}-\mathrm{H}$ and triazolium $\mathrm{C}-\mathrm{H}$ signals confirmed the formation of the triply deprotonated compound 3. In the ${ }^{13} \mathrm{C}\left\{{ }^{1} \mathrm{H}\right\}$ NMR spectrum, a singlet at $195 \mathrm{ppm}$, characteristic of a $\mathrm{K}-\mathrm{C}_{\text {carbene }}$ adduct, was observed. ${ }^{10}$ Interestingly, the bis(carbene)amido potassium adduct is indefinitely stable in solution and in the solid state, in the absence of oxygen and water. 


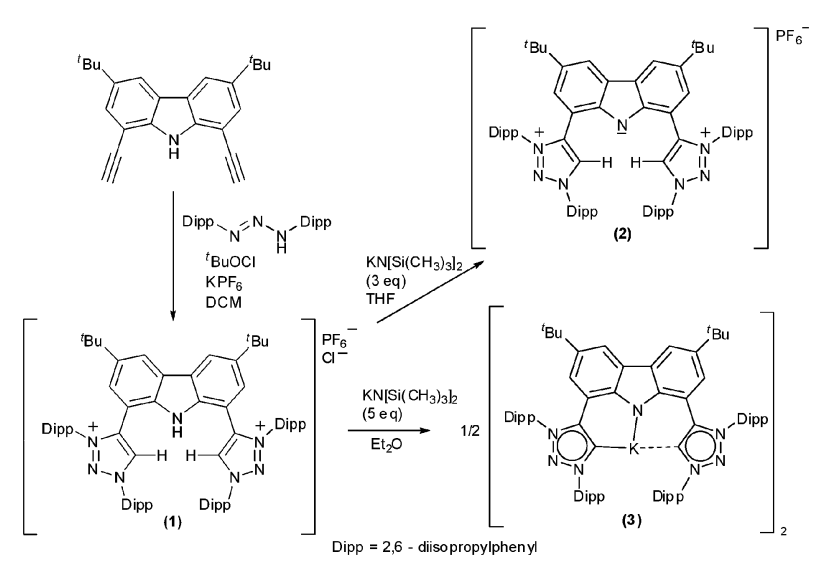

Scheme 1 Synthesis of ligand precursors $\mathbf{1}$ and $\mathbf{2}$, and ligand $\mathbf{3}$.
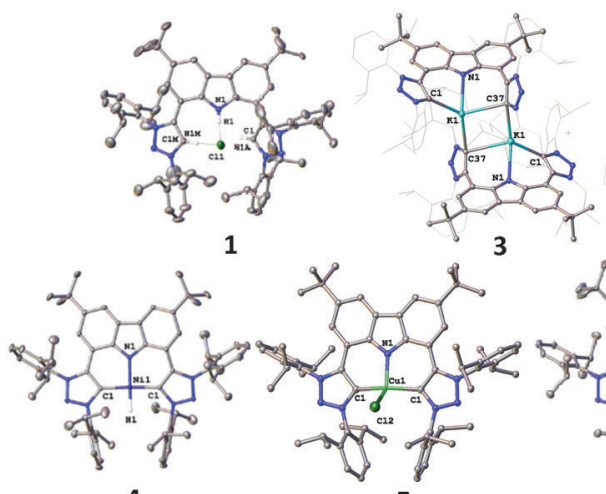

4
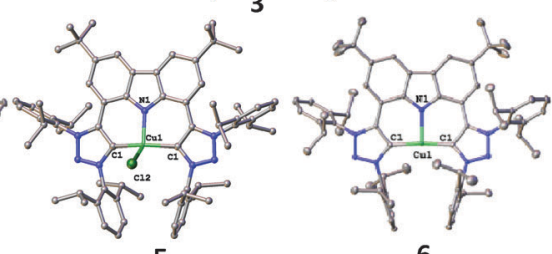

6

Fig. 1 Molecular structures of 1, 3-6 (thermal ellipsoids at 50\% probability level). Hydrogen atoms (except triazolium $\mathrm{C}-\mathrm{H}$ 's, $\mathrm{N}-\mathrm{H}$ and $\mathrm{Ni}-\mathrm{H}$ ), solvent molecules and counteranions $\left(\mathrm{PF}_{6}{ }^{-}\right)$were omitted for clarity except in the case of $\mathbf{1}$. The diisopropylphenyl-groups of $\mathbf{3}$ were drawn as wireframe structures for the sake of clarity.

Crystals of 3, suitable for an X-ray diffraction study, were obtained from a mixture of deuterated benzene and toluene. The structure of 3 (Fig. 1) features a [(CNC)-K-K-(CNC)] dimer centered on a distorted rhombic $\mathrm{K}_{2} \mathrm{C}_{2}$ core, with the two threecoordinated potassium atoms acting as a bridge between two CNC ligands. The two 1,2,3-triazol-5-ylidene rings are planar with bond distances between that found for single and double bonds, and are not coplanar with the carbazolide backbone. The bond angles $\left[\mathrm{N} 2-\mathrm{C} 1-\mathrm{C} 2=100.49(14)^{\circ}\right]$ and $[\mathrm{N} 5-\mathrm{C} 37-\mathrm{C} 38=$ $\left.100.66(15)^{\circ}\right]$ in 3 are more acute than the corresponding angle $\left[\mathrm{N} 2-\mathrm{C} 1-\mathrm{C} 2=104.06(19)^{\circ}\right]$ in 1 as always observed when comparing a carbene and its precursor. ${ }^{4}$ Each potassium binds to one $\mathrm{N}$ atom and one carbene carbon from a $\mathrm{CNC}$ unit plus one carbene carbon from the adjacent (CNC) ligand. The bond distances $\left(\mathrm{K} 1-\mathrm{N} 1=2.624(15) ; \mathrm{K} 1-\mathrm{C} 1=2.869(17) ; \mathrm{K} 1-\mathrm{C} 37^{\prime}=\right.$ $2.9684(19) \AA)$ are well in accordance with other potassiumcarbene bond lengths of 3.000(13)-3.048 $\AA{ }^{10}$ additionally, long carbon-K distances are observed (K1-C37 = 3.158(17) ̊̊). ${ }^{10 b}$

When the cationic pincer derivative 1 was reacted with excess base and 1.1 equivalent of nickel(II) dichlorodimethoxyethane adduct ([Ni(DME) $\left.\left.\mathrm{Cl}_{2}\right]\right)$ in THF at $-78{ }^{\circ} \mathrm{C}$, the unexpected nickel-hydride complex [(CNC)NiH] 4 was obtained in 39\% yield (Scheme 2).

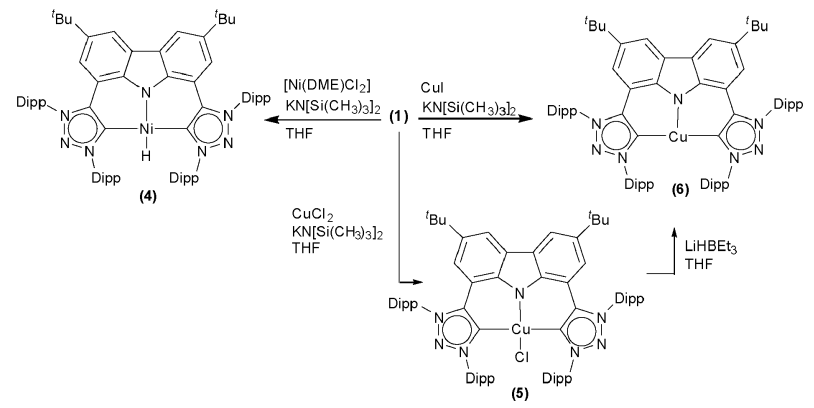

Scheme 2 Synthesis of complexes 4-6.

A characteristic hydride signal appears at $-6.30 \mathrm{ppm}$ in the ${ }^{1} \mathrm{H}$ NMR spectrum, and a single crystal X-ray diffraction study confirmed the structural assignment (Fig. 1). Note that two cationic Ni(carbene)-hydride complexes have been reported to date, ${ }^{11}$ complex 4 being the first example of an isolated neutral $\mathrm{Ni}$-carbene hydride complex. Formation of the hydride complex is presumed to occur via the triazolium $\mathrm{C} 5-\mathrm{H}$ activation, similar to the $\mathrm{C} 2-\mathrm{H}$ activation of the imidazolium ring observed by Cavell et al. ${ }^{11 a}$ The molecular structure (Fig. 1) shows a distorted square planar geometry around the Ni center, analogous to other nickel hydride complexes featuring pincer ligands with a central amidoligating atom, ${ }^{12}$ and with comparable Ni-N1 and Ni-H1 bondlengths (see ESI $\dagger$ ) to these ${ }^{12}$ and other $\mathrm{Ni}-\mathrm{H}$ pincer complexes. ${ }^{13}$ The two 2,6-diisopropylphenyl groups (Dipp) of the mesoionic carbenes shield the hydride. The 1,2,3-triazol-5-ylidenes rings are not coplanar with the carbazolide backbone: both rings are tilted $\left[\mathrm{C} 4-\mathrm{C} 3-\mathrm{C} 2-\mathrm{C} 1=-7.7(3)^{\circ}\right]$. The two mesoionic carbenes and the metal center (C1-N1-C1) form an angle of 177.56(10) $)^{\circ}$

Encouraged by the stability of the $\mathrm{Ni}-\mathrm{H}$ complex 4 , the synthesis of the first example ${ }^{14}$ of a $\mathrm{Cu}$ (II)-H complex was attempted. Following a similar procedure as described above, $\mathrm{CuCl}_{2}$ was employed as starting material (Scheme 2), and the paramagnetic [(CNC)Cu(II)Cl] complex 5 was obtained in $86 \%$ yield.

Although the $\mathrm{Cu}(\mathrm{II})$-carbene fragment is implicated in copper catalysed carbene transfer reactions, it is usually too reactive to be isolated. ${ }^{15}$ Again, only two other examples of $\mathrm{Cu}(\mathrm{II})$-carbene complexes are known. ${ }^{16}$ No usable NMR data could be obtained due to the paramagnetic nature of the complex, but the single crystal data confirms the structure of this unusual carbene complex. The C2-C1-Cu1-C1 torsion angle of $110.64(5)^{\circ}$ displays significant deviation from planarity, and the Cl1-Cu1-N1 bond angle of $123.53(6)^{\circ}$ is indicative more of an unusual seesaw geometry than the expected square planar arrangement around the Cu-atom. ${ }^{16,17}$ Attempts at substituting the chloro ligand with a hydrido employing superhydride (LiHBEt ${ }_{3}$ ) proved unsuccessful; it resulted in the reduction of $\mathrm{Cu}$ (II) to $\mathrm{Cu}(\mathrm{I})$ and the formation of the brown-colored complex 6 [(CNC)Cu(I)] (Scheme 2). An independent route, utilizing CuI, KHMDS and $\mathbf{1}$ as precursor, also led to the isolation of 6. An X-ray diffraction study (Fig. 1) revealed the rarely found "naked" slightly distorted T-shape geometry of the $\mathrm{Cu}(\mathrm{I}),{ }^{16,18}$ in which the metal center is coordinated to the central amido and two mesoionic carbenes. The 1,2,3-triazol-5-ylidenes rings are both tilted from the plane of 
the carbazolide backbone $\left[\mathrm{C} 8-\mathrm{C} 3-\mathrm{C} 2-\mathrm{C} 1=9.8(3)^{\circ}\right]$, and the $\mathrm{N} 1-\mathrm{Cu}$ bond $[2.017(2) \AA]$ is slightly longer than the $\mathrm{N} 1-\mathrm{Cu}$ bond in 5 [1.956(3) ̊̊]. Mono- and dinuclear carbene ligands usually result in the formation of linear copper complexes, ${ }^{19}$ while sterically less bulky carbene ligands form Y-shaped complexes. ${ }^{17 c}$

To summarize, the novel anionic CNC-bisMIC ligand with its highly electron-donating backbone allows for the isolation and structural characterization of unusually stable transition metal species that have traditionally been viewed as not isolable under ambient conditions.

This work was supported by the National Research Foundation of South Africa, (DIB, Grant number 76226), the Fulbright Scholar Program (DIB), and the DOE (GB, DE-FG02-13ER16370).

\section{Notes and references}

1 For reviews, see: (a) G. van Koten, J. Organomet. Chem., 2013, 730, 156; (b) Organometallic Pincer Chemistry, Top. Organomet. Chem., ed. G. van Koten and D. Milstein, Springer-Verlag, Berlin, 2013, vol. 40 and chapters therein; (c) C. Redshaw and Y. Tang, Chem. Soc. Rev., 2012, 41, 4484; (d) M. C. Haibach, S. Kundu, M. Brookhart and A. S. Goldman, Acc. Chem. Res., 2012, 45, 947; (e) D. Gelman and S. Musa, ACS Catal., 2012, 2, 2456; $(f)$ J. Choi, A. H. Roy MacArthur, M. Brookhart and A. S. Goldman, Chem. Rev., 2011, 111, 1761; $(g)$ N. Selander and K. J. Szabo, Chem. Rev., 2011, 111, 2048; (h) M. Albrecht and M. M. Lindner, Dalton Trans., 2011, 40, 8733; $(i)$ H. Zhang and A. Lei, Dalton Trans., 2011, 40, 8745; (j) R. A. Gossage, Dalton Trans., 2011, 40, 8755; ( $k$ ) W. Leis, H. A. Mayer and W. C. Kaska, Coord. Chem. Rev., 2008, 252, 1787; (l) M. Albrecht and G. van Koten, Angew. Chem., Int. Ed., 2001, 40, 3750.

2 For examples of NHC pincer-type ligands see reviews: (a) S. Budagumpi, R. A. Haque and A. W. Salman, Coord. Chem. Rev., 2012, 256, 1787; (b) M. Poyatos, J. A. Mata and E. Peris, Chem. Rev., 2009, 109, 3677; (c) D. Pugh and A. A. Danopoulos, Coord. Chem. Rev., 2007, 251, 610; (d) J. A. Mata, M. Poyatos and E. Peris, Coord. Chem. Rev., 2007, 251, 841; (e) X. Hu and K. Meyer, J. Organomet. Chem., 2005, 690, 5474; $(f)$ E. Peris and R. H. Crabtree, Coord. Chem. Rev., 2004, 248, 2239.

3 (a) R. E. Douthwaite, J. Houghton and B. Kariuki, Chem. Commun., 2004, 698; (b) W. Wei, Y. Quin, M. Luo, P. Xia and M. S. Wong, Organometallics, 2008, 27, 2268; (c) W. B. Cross, C. G. Daly, R. L. Ackerman, I. R. George and K. Singh, Dalton Trans., 2011, 40, 495; (d) M. Moser, B. Wucher, D. Kunz and F. Rominger, Organometallics, 2007, 26, 1024.

4 For recent reviews on mesoionic carbenes see: (a) K. F. Donnelly, A. Petronilho and M. Albrecht, Chem. Commun., 2013, 47, 1145; (b) R. H. Crabtree, Coord. Chem. Rev., 2013, 257, 755; (c) M. Melaimi, M. Soleilhavoup and G. Bertrand, Angew. Chem., Int. Ed., 2010, 49, 5304; (d) D. Martin, M. Melaimi, M. Soleilhavoup and G. Bertrand, Organometallics, 2011, 30, 5304; (e) A. Poulain, M. Iglesias and M. Albrecht, Curr. Org. Chem., 2011, 15, 3325; $(f)$ A. Kruger and M. Albrecht, Aust. J. Chem., 2011, 64, 1113; (g) M. Albrecht, Chimia, 2009, 63, 105; $(h)$ O. Schuster, L. Yang, H. G. Raubenheimer and M. Albrecht, Chem. Rev., 2009, 109, 3445; (i) P. L. Arnold and S. Pearson, Coord. Chem. Rev., 2007, 251, 596.

5 (a) A. Kruger, L. J. L. Haller, H. Muller-Bunz, S. O. Serada, A. A. Neels, S. A. MacGregor and M. Albrecht, Dalton Trans., 2011, 40, 9911; (b) W. W. Zuo and P. Braunstein, Organometallics, 2012, 31, 2606; (c) K. F. Donnelly, A. Petronilho and M. Albrecht, Chem. Commun., 2013, 49, 1145.

6 (a) J. Bouffard, B. K. Keitz, R. Tonner, G. Guisado-Barrios, G. Frenking and G. Bertrand, Organometallics, 2011, 30, 2617; (b) G. Guisado-Barrios, J. Bouffard, B. Donnadieu and G. Bertrand, Angew. Chem., Int. Ed., 2010, 49, 4759; (c) P. Mathew, A. Neels and M. Albrecht, J. Am. Chem. Soc., 2008, 130, 13534.

7 (a) E. O. Keske, O. V. Zenkina, R. Y. Wang and C. M. Crudden, Organometallics, 2012, 31, 456; (b) M. T. Zamara, M. J. Ferguson and M. Cowie, Organometallics, 2012, 31, 5384.

8 T. Karthikeyan and S. Sankararaman, Tetrahedron Lett., 2009, 50, 5834.

9 (a) D. G. Brown, N. Sanguantrakun, B. Schulze, U. S. Shubert and C. P. Berlinguette, J. Am. Chem. Soc., 2012, 134, 12354; (b) B. Schulze, D. Escudero, C. Friebe, R. Siebert, H. Gorls, U. Kohn, E. Altuntas, A. Baumgaertel, M. D. Hager, A. Winter, B. Dietzek, J. Popp, L. Gonzalez and U. S. Shubert, Chem.-Eur. J., 2011, 17, 5494.

10 (a) M. S. Hill, G. Kociok-Köhn and D. J. MacDougall, Inorg. Chem., 2011, 50, 5234; (b) P. L. Arnold, M. Rodden and C. Wilson, Chem. Commun., 2005, 1743; (c) R. W. Alder, M. E. Blake, C. Borlotti, S. Bufali, C. P. Butts, E. Linehan, J. M. Oliva, A. G. Orpen and M. J. Quale, Chem. Commun., 1999, 241; (d) M. Otto, S. Conejero, Y. Canac, V. D. Romanenko, V. Rudzevitch and G. Bertrand, J. Am. Chem. Soc., 2004, 126, 1016.

11 (a) M. D. Clement, K. J. Cavell, C. Jones and C. J. Elsevier, Angew. Chem., Int. Ed., 2004, 43, 1277; (b) T. Steinke, B. K. Shaw, H. Jong, B. O. Patrick, M. D. Fryzuk and J. C. Green, J. Am. Chem. Soc., 2009, 131, 10461.

12 (a) J. Breitenfeld, R. Scopelliti and X. Hu, Organometallics, 2012, 31, 2128; (b) L.-C. Liang, P.-S. Chien and P.-Y. Lee, Organometallics, $2008,27,3082$.

13 (a) S. Chakraborty, J. A. Krause and H. Guan, Organometallics, 2009, 28, 582; (b) B. J. Boro, E. N. Duesler, K. I. Goldberg and R. A. Kemp, Inorg. Chem., 2009, 48, 5081.

14 For di- and polymeric copper(I) hydrides, see: (a) M. S. Eberhart, J. R. Norton, A. Zuzek, W. Sattler and S. Ruccolo, J. Am. Chem. Soc., 2013, 135, 17262; (b) G. D. Frey, B. Donnadieu, M. Soleilhavoup and G. Bertrand, Chem.-Asian J., 2011, 6, 402; (c) Z. Mao, J.-S. Huang, C.-M. Che, N. Zhu, S. K.-Y. Leung and Z.-Y. Zhou, J. Am. Chem. Soc., 2005, 127, 4562; (d) B. H. Lipshutz and B. A. Frieman, Angew. Chem., Int. Ed., 2005, 44, 6345; (e) N. P. Mankad, D. S. Laitar and J. P. Sadighi, Organometallics, 2004, 23, 3369; $(f)$ C. F. Albert, P. C. Healy, J. D. Kildea, C. L. Raston, B. W. Skelton and A. H. White, Inorg. Chem., 1989, 28, 1300; $(g)$ W. S. Mahoney and J. M. Stryker, J. Am. Chem. Soc., 1989, 111, 8818; (h) W. S. Mahoney, D. M. Brestensky and J. M. Stryker, J. Am. Chem. Soc., 1988, 110, 291; (i) T. H. Lemmen, K. Folting, J. C. Huffman and K. G. Caulton, J. Am. Chem. Soc., 1985, 107, 7774; (j) G. V. Goeden, J. C. Huffman and K. G. Caulton, Inorg. Chem., 1984, 25, 2484; $(k)$ S. A. Bezman, M. R. Churchill, J. A. Osborn and J. Wormald, J. Am. Chem. Soc., 1971, 93, 2063.

15 (a) J. M. Frale, J. I. Garcia, V. Martinez-Merino, J. A. Mayoral and L. Salvatella, J. Am. Chem. Soc., 2001, 123, 7616; (b) M. P. Doyle and D. C. Forbes, Chem. Rev., 1998, 98, 911.

16 (a) P. L. Arnold, M. Rodden, K. M. Davis, A. C. Scarisbrick, A. J. Blake and C. Wilson, Chem. Commun., 2004, 1612; (b) X. Hu, I. CastroRodriguez and K. Meyer, J. Am. Chem. Soc., 2003, 125, 12237.

17 (a) P. J. Donoghue, A. K. Gupta, D. W. Boyce, C. J. Cramer and W. B. Tolman, J. Am. Chem. Soc., 2010, 132, 15869; (b) D. Petrovic, T. Bannenberg, S. Randall, P. G. Jones and M. Tamm, Dalton Trans., 2007, 2812; (c) E. Digard and J. Andrieu, Inorg. Chem. Commun., 2012, 25, 39; (d) G. Venkatachalam, M. Heckenroth, A. Neels and M. Albrecht, Helv. Chim. Acta, 2009, 92, 1034.

18 J. A. Flores, J. G. Andino, N. P. Tsvetkov, M. Pink, R. J. Wolfe, A. R. Head, D. L. Lichtenberger, J. Massa and K. G. Caulton, Inorg. Chem., 2011, 50, 8121.

19 (a) L. Zhang, J. Cheng and Z. Hou, Chem. Commun., 2013, 49, 4782; (b) A. Petronilho, H. Muller-Bunz and M. Albrecht, Chem. Commun., 2012, 48, 6499; (c) H. Kaur, F. Kauer Zinn, E. D. Stevens and S. P. Nolan, Organometallics, 2004, 23, 1157. 